\title{
A Chrysobalanus icaco extract alters the plasmid topology and the effects of stannous chloride on the DNA of plasmids
}

\author{
Giuseppe A. Presta ${ }^{1,2,4 *}$, Adenilson S. Fonseca ${ }^{2}$, Mario Bernardo-Filho ${ }^{2,3}$ \\ ${ }^{1}$ Universidade Federal do Rio Grande do Norte, Programa de Pós-Graduação em Ciências da Saúde, Av. Gal. \\ Gustavo Cordeiro de Farias, s/n, 59010-180, Natal, RN, Brasil, \\ ${ }^{2}$ Universidade do Estado do Rio de Janeiro, Instituto de Biologia Roberto Alcântara Gomes, Departamento de \\ Biofísica e Biometria, Av. 28 de Setembro 87, 20551-030, Rio de Janeiro, RJ, Brasil, \\ ${ }^{3}$ Instituto Nacional do Câncer, Coordenadoria de Pesquisa Básica, Praça Cruz Vermelha 23, 20230-130, \\ Rio de Janeiro, RJ, Brasil, \\ ${ }^{4}$ Universidade Federal do Estado do Rio de Janeiro, Instituto Biomédico, Departamento de Ciências \\ Fisiológicas, Rua Frei Caneca 94, 20211-040, Rio de Janeiro, RJ, Brasil
}

\begin{abstract}
RESUMO: "Um extrato de Chrysobalanus icaco altera a topologia de plasmídios e os efeitos do cloreto estanoso sobre o DNA de plasmídios". Folhas de Chrysobalanus icaco $(C$. icaco) são usadas na medicina popular (conhecido como Abajeru no Brasil) para controlar a glicemia em pacientes diabéticos. Cloreto estanoso $\left(\mathrm{SnCl}_{2}\right)$ é um agente redutor potente usado para diferentes propostas e apresenta efeitos citotóxico e genotóxico. O objetivo deste trabalho foi investigar os efeitos de um extrato aquoso de C. icaco na topologia de DNA plasmidial e nos efeitos do cloreto estanoso sobre o DNA plasmidial. Plasmídios pBSK foram incubados com um extrato de $C$. icaco na presença ou ausência do $\mathrm{SnCl}_{2}(200 \mathrm{mg} / \mathrm{mL})$, em seguida, o procedimento de eletroforese em gel de agarose foi realizado. Plasmídios incubados somente com $\mathrm{SnCl}_{2}$ foram usados como controle positivo e, como controle negativo, plasmídios incubados com tampão Tris. Os géis foram corados com brometo de etídio e as bandas de DNA foram semiquantificadas por densitometria. Os dados mostraram que o extrato de C. icaco altera o perfil eletroforético e diminui significativamente $(\mathrm{p}<0,05)$ os efeitos do $\mathrm{SnCl}_{2}$ sobre DNA plasmidial. Os resultados obtidos neste trabalho indicam uma ação protetora dependente da dose e um efeito genotóxico de extrato de C. icaco sobre o DNA plasmidial.
\end{abstract}

Unitermos: Chrysobalanus icaco, Chrysobalanaceae, DNA plasmidial, cloreto estanoso, efeito genotóxico, antioxidante.

\begin{abstract}
Chrysobalanus icaco (C. icaco) leaves are used in folk medicine (known as Abajeru in Brazil) to control the glycaemia in diabetic patients. Stannous chloride $\left(\mathrm{SnCl}_{2}\right)$ is a powerful reducing agent used for different purposes and presents cytotoxic and genotoxic effects. The aim of this work was to investigate the effect of an aqueous $C$. icaco extract on the plasmid DNA topology and on the effects of the stannous chloride on DNA plasmid. Plasmid pBSK was incubated with a C. icaco extract in the presence or absence of $\mathrm{SnCl}_{2}(200 \mathrm{mg} / \mathrm{mL})$, after that, the agarose gel electrophoresis procedure was carried out. Plasmid incubated only $\mathrm{SnCl}_{2}$ was used as positive control and, as negative control, plasmid incubated with Tris buffer. The gels were stained with ethidium bromide, DNA bands were semiquantified by densitometry. The data showed that $C$. icaco extract alters the electrophoretic profile and decreases significantly $(\mathrm{p}<$ 0.05 ) the effect of $\mathrm{SnCl}_{2}$ on plasmid DNA. The results obtained in this work could indicate a dose-dependent protective action and a genotoxic effect of $C$. icaco extract on plasmid DNA.
\end{abstract}

Keywords: Chrysobalanus icaco, Chrysobalanaceae, plasmid DNA, stannous chloride, genotoxic effect, antioxidant.

\section{INTRODUCTION}

Chrysobalanus icaco. (C. icaco), also known as "coco plum", "icaco", "agirú", is an evergreen, medium-sized shrub or, rarely, a small tree with leathery, dark-green, round to oval leaves belonging to Chrysobalanaceae family (Mendez et al., 1995; Coradin et al., 1985).

The species are native to coastal areas of southern Florida, the Bahamas and through the Caribbean. It is also found through Central and South America, including Mexico, Ecuador and Northern Brazil as well as tropical Africa (Little et al., 1974). In Brazil, 
aqueous extracts of $C$. icaco leaves (Chrysobalanaceae family) are commonly used in Brazilian traditional medicine to control the glycaemia of diabetic patients (Costa, 1977; Barbosa-Filho et al., 2005; Agra et al., 2007).

Earlier studies have reported the trienoic, tetraenoic acids and their oxo derivatives (Gunstone; Subbarao 1967) and catechol tannins (Verma; Raychaudhuri, 1972) in seed oil of C. icaco. The presence of diterpenes and triterpenes in the leaves of $C$. icaco were also reported (Fernandes et al., 2003; Gustafson; Munro, 1991). Phytochemical investigations of C. icaco extracts have reported the presence of myricetin in $C$. icaco leaf (Mendez et al., 1995; Fernandes et al., 2003; Gustafson; Munro, 1991; Barbosa et al., 1996).

Stannous chloride $\left(\mathrm{SnCl}_{2}\right)$ is a powerful reducing agent used for packing canned food, in dental amalgams and for preparing ${ }^{99 \mathrm{~m}}$ Technetiumradiopharmaceuticals. Previous studies have demonstrated that stannous chloride is capable to inactivate Escherichia coli cultures (Melo et al., 2001) and K562 cells (Dantas et al., 2002) as well as to induce single strand breaks in plasmid DNA through generation of free radicals in vitro (Dantas et al., 1999; FerreiraMachado et al., 2004).

The aim of this work was to investigate the effect of an aqueous $C$. icaco extract on the plasmid DNA topology and also on the effects of the stannous chloride on plasmid DNA.

\section{MATERIAL AND METHODS}

\section{Drugs}

Commercial C. icaco was used in this study and it is purchased from Estrella da Terra Produtos Naturais Ltda, Rio de Janeiro (lot 12, validity March 2009) and stannous chloride $\left(\mathrm{SnCl}_{2}\right)$ was purchased form Sigma Chemicals Co. (USA).

\section{Plasmid DNA}

To obtain pBSK plasmid, cultures in LB medium (Miller, 1992) with ampicillin $(100 \mathrm{mg} / \mathrm{mL})$ of $E$. coli DH5aF'Iq (rec-) strain hosting this plasmid was carried out (18 hours, $\left.37^{\circ} \mathrm{C}\right)$. The pBSK plasmid, carrying an ampicillin resistance gene, was obtained through alkaline cell lysis method (Sambrook et al., 1989).

\section{Plasmid treatment with $C$. icaco extract}

To evaluate the action of aqueous $C$. icaco extract on DNA topology, plasmid pBSK was incubated at different concentrations of this extract $(0.5,5,50$ $\mathrm{mg} / \mathrm{mL}$ ). To assess the action of $C$. icaco extract on effects of $\mathrm{SnCl}_{2}$, plasmid pBSK was incubated with this extract, at the same concentration, in presence of $\mathrm{SnCl}_{2}(200 \mathrm{mg} / \mathrm{mL})$. Plasmid incubated only with $\mathrm{SnCl}_{2}$ was used as positive control and, as negative control, plasmid incubated at $10 \mathrm{mM}$ Tris buffer (vehicle, $\mathrm{pH}$ 7.4). The incubations were carried out at room temperature for 40 minutes. After that, each sample was mixed with loading buffer $(0.25 \%$ xylene cyanol, $0.25 \%$ bromophenol blue and glycerol in water) and applied in $0.8 \%$ agarose horizontal gel electrophoresis chamber in Tris-acetate-EDTA buffer at $\mathrm{pH} 8.0$ and run at $7 \mathrm{~V} /$ $\mathrm{cm}$. The electrophoresis procedure was performed to separate the structural conformations of plasmid DNA as such:1) supercoiled native conformation (form I) and 2) open circle (form II). The gel was stained with ethidium bromide $(0.5 \mathrm{mg} / \mathrm{mL})$ and the DNA bands were visualized by fluorescence under an ultraviolet transilumination system. The assay was repeated at least four times, the results were digitalized (Kodak Digital Science 1d, EDAS 120) and the bands semiquantified using the computer program Gimp 2 for Windows.

\section{Statistical analysis}

Data are reported as percentage of form I and form II (means \pm standard deviation). These were compared between the treated and control groups by One way analysis of variance - ANOVA, followed by Bonferroni post test with a $p<0.05$ as level of significance. InStat Graphpad software was used to perform statistical analysis (GraphPad InStat version 3.00 for Windows 95, GraphPad Software, San Diego, USA).

\section{RESULTS}

The Figure 1 shows the photograph of agarose gel electrophoresis of pBSK plasmid treated with $C$. icaco extract in presence and absence of $\mathrm{SnCl}_{2}$. This figure shows that after incubation with $C$. icaco extract at the higher concentration used in absence (lane 3 ) or presence (lane 6) of $\mathrm{SnCl}_{2}$ the electrophoretic profile of plasmid DNA was altered and the form I (supercoiled) and form II (open circle) of plasmid DNA were not present. When plasmid DNA was incubated with $C$. icaco extract at lowest concentrations $(5.0$ and $0.5 \mathrm{mg} /$ $\mathrm{mL})$, there was no alteration of electrophoretic profile of plasmid DNA (lanes 4 and 5). Also, C. icaco extract, at these lowest concentrations, was capable of protect the DNA plasmid of the electrophoretic profile changes induced by $\mathrm{SnCl}_{2}$ (lanes 7 and 8 ).

To quantify the changes in the topology of plasmid DNA, the percentage of forms I and II were determined by a semiquantitative densitometric method (Figure 2). This figure shows that the percentage of form I and II of pBSK plasmid could be modified by treatment with the aqueous $C$. icaco extract, at the higher 


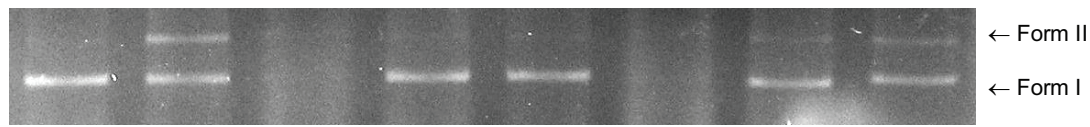

$\begin{array}{lllllllll}1 & 2 & 3 & 4 & 5 & 6 & 7 & 8\end{array}$

Figure 1. Photograph of agarose gel electrophoresis of plasmid $\mathrm{pBSK}+$ treated with an aqueous $C$. icaco extract in the presence and absence of $\mathrm{SnCl}_{2}$. Plasmids incubated with vehicle (Tris buffer) was used as negative control and plasmid incubated with $\mathrm{SnCl}_{2}(200 \mu \mathrm{g} / \mathrm{mL})$, as positive control. Each sample was mixed with loading buffer and submitted to $0.8 \%$ agarose gel electrophoresis. Lanes: (1) $\mathrm{pBSK}$, negative control; (2) $\mathrm{pBSK}+\mathrm{SnCl}_{2}$, positive control; (3) $\mathrm{pBSK}+C$. icaco extract $(50 \mathrm{mg} / \mathrm{ml}) ;(4) \mathrm{pBSK}+$ C. icaco extract $(5 \mathrm{mg} / \mathrm{mL}) ;(5) \mathrm{pBSK}+$ C. icaco extract $(0.5 \mathrm{mg} / \mathrm{mL}) ;(6) \mathrm{pBSK}+$ C. icaco extract $(50 \mathrm{mg} / \mathrm{mL})+\mathrm{SnCl}_{2}$; (7) $\mathrm{pBSK}+$ C. icaco extract $(5 \mathrm{mg} / \mathrm{mL})+\mathrm{SnCl}_{2}$; (8) $\mathrm{pBSK}+$ C. icaco extract $(0.5 \mathrm{mg} / \mathrm{mL})+\mathrm{SnCl}_{2}$. The experiments were performed three times.

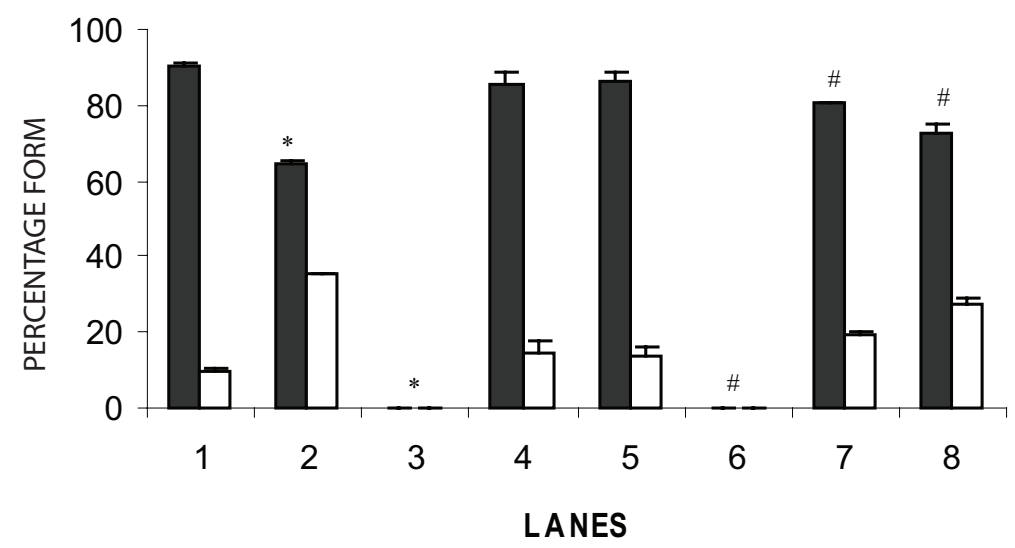

Figure 2. The percentage of plasmid $\mathrm{pBSK}+$ in the form I and II treated with an aqueous $C$. icaco extract in the presence or absence of $\mathrm{SnCl}_{2}$. Plasmids incubated with vehicle $\left(\mathrm{H}_{2} \mathrm{O}\right)$ were used as negative control while plasmids with $\mathrm{SnCl}_{2}(200$ $\mu \mathrm{g} / \mathrm{mL}$ ) used as positive control. Each sample was mixed with loading buffer and submitted to $0.8 \%$ agarose gel electrophoresis. Every set of experiments was quadruplicated $(\mathrm{n}=4)$. Lanes: (1) $\mathrm{pBSK}$, negative control; (2) $\mathrm{pBSK}+\mathrm{SnCl}_{2}$, positive control; (3) pBSK + C. icaco extract $(50 \mathrm{mg} / \mathrm{mL})$; (4) $\mathrm{pBSK}+$ C. icaco extract $(5 \mathrm{mg} / \mathrm{mL}) ;(5) \mathrm{pBSK}+$ C. icaco extract $(0.5 \mathrm{mg} / \mathrm{mL}) ;(6) \mathrm{pBSK}+$ C. icaco extract $(50 \mathrm{mg} / \mathrm{mL})+\mathrm{SnCl}_{2} ;(7) \mathrm{pBSK}+$ C. icaco extract $(5 \mathrm{mg} / \mathrm{mL})+\mathrm{SnCl}_{2} ;$ (8) $\mathrm{pBSK}+$ C. icaco extract $(0.5 \mathrm{mg} / \mathrm{mL})+\mathrm{SnCl}_{2}$. (a) form I (supercoiled), ( $\square$ ) form II (open circle). $\left(^{*}\right) \mathrm{p}<0.05$ when compared with negative control (Lane 1). (\#) $\mathrm{p}<0.05$ when compared to positive control (lane 2). 
concentration used. In addition, the data presented in figure 2 indicate that the effects of $\mathrm{SnCl}_{2}$ could be decreased by $C$. icaco extract at lowest concentrations. Moreover, the semiquantitative analysis presented in figure 2, confirms the qualitative analysis based on figure 1 , there were significant differences in every lane when the control group was compared with the various concentrations of $C$. icaco, with or without $\mathrm{SnCl}_{2}$.

\section{DISCUSSION}

The genotoxic effect of stannous chloride on DNA has been demonstrated by different experimental models and the mechanism action has been so far related to free radicals generation (Javor et al., 1986; Melo et al. 2001, Dantas et al. 2002, Guedes et al. 2006). In fact, the presence of free radicals scavengers can reduce the changes of electrophoretic profile of plasmid DNA induced by stannous chloride decreasing the DNA strand breaks (Dantas et al. 1999, de Mattos et al., 2000). Moreover, these conformational changes induced by stannous chloride have been used as experimental model to evaluate the either the redoxi, chelating or scavenger potentials of natural products such as $C$. icaco (Simões et al. 2006).

The data obtained in this work indicate that aqueous $C$. icaco extract decreases the genotoxic effect of stannous chloride on plasmid DNA (Figures 1 and 2) suggesting a protective action to this extract. This effect of $C$. icaco extract may well occur at lowest concentrations while, at highest concentrations, this extract could present a strong genotoxic effect (Figure 1, lanes 3 and 6). The data of genotoxic effect of this extract is in according with the results obtained for other authors (Ferreira-Machado et al. 2004) using a different method to prepare the extract of $C$. icaco. As the two extracts were prepared using two different methods, our findings are important due to the extract used in this work represents a situation that is commonly used by the population.

Another relevant finding of our work is that is possible to suggest an important protective effect of $C$. icaco extract against the stannous chloride. Moreover, this result with $C$. icaco and several other natural and synthetic substances have not been described yet by other authors.

The paradoxical results in this work could be explained by presence of different substances in aqueous C. icaco extract used. Dependent on the concentration, these compounds could be capable to induce lesions in DNA altering the electrophoretic profile in agarose gels or to protect the same molecule against chemical agents as stannous chloride.

Thus, some compounds (triterpenoids) in $C$. icaco extract demonstrate cytotoxic effect mainly by apoptosis (Fernandes et al. 2003) while other effects could be beneficial on human health. This extract can be used to treat several diseases such as leucorrhea, haemorrhages, diarrhea in folk medicine or as hypoglycemic and antiangiogenic agent (Costa, 1977; Alves-de-Paulo et al., 2000).

In conclusion, the results obtained in this work could indicate a dose-dependent protective action and a genotoxic effect to $C$. icaco extract on plasmid DNA.

\section{ACKNOWLEDGEMENTS}

This research was supported by Fundação de Amparo a Pesquisa do Estado do Rio de Janeiro (FAPERJ), Conselho Nacional de Desenvolvimento Científico e Tecnológico (CNPq) and Universidade do Estado do Rio de Janeiro (UERJ).

\section{REFERENCES}

Agra MF, França PF, Barbosa-Filho JM 2007. Synopsis of the plants known as medicinal and poisonous in Northeast of Brazil. Rev Bras Farmacogn 17: 114140.

Alves de Paulo S, Balassiano IT, Silva NH, Castilho RO, Kaplan MAC, Cabral MC, Carvalho MGC 2000. Chrysobalanus icaco L. extract for antiangiogenic potential observation. Int J Mol Med 5: 667-669.

Barbosa WLR, Peres A, Gallori S, Vincieri FF 2006. Determination of myricetin derivatives in Chrysobalanus icaco L. (Chrysobalanaceae). Rev Bras Farmacogn 16: 333-337.

Barbosa-Filho JM, Vasconcelos THC, Alencar AA, Batista LM, Oliveira RAG, Guedes DN, Falcão HS, Moura MD, Diniz MFFM, Modesto-Filho J 2005. Plants and their active constituents from South, Central, and North America with hypoglycemic activity. Rev Bras Farmacogn 15: 392-413.

Coradin L, Giannasi DE, Prance AT 1985. Chemosystematic studies in the Chrysobalanaceae. Flavonoids in Parinari. Brittonia 37: 169-178.

Costa OA 1977. Brazilian plants with hypoglycaemic effects. Leandra 7: 63-75.

Dantas FJS, Moraes MO, De Mattos JCP, Bezerra RJAC, Carvalho EF, Bernardo-Filho M, Caldeira-de-Araújo A 1999. Stannous chloride mediates single strand breaks in plasmid DNA. Toxicol Lett 110: 129-136.

Dantas FJS, De Mattos JCP, Viana ME, Lage CAS, CabralNeto JB, Leitão AC, Bernardo-Filho M, Bezerra RJAC, Carvalho JJ, Caldeira-de-Araújo A 2002. Genotoxic effects of stannous chloride $\left(\mathrm{SnCl}_{2}\right)$ in K562 cell line. Food Chem Toxicol 40: 1493-1498.

De Mattos JCP, Dantas FJS, Bezerra RJAC, Bernardo-Filho M, Cabral-Neto JB, Lage CAS, Leitão AC, Caldeirade-Araújo A 2000. Damage induced by stannous chloride in plasmid DNA. Toxicol Lett 116: 159163.

Fernandes J, Castilho RO, Costa MR, Wagner-Souza K, Kaplan MAC, Gattass CR 2003. Pentacyclic triterpenes from Chrysobalanaceae species: cytotoxicity on multidrug resistant and sensitive leukemia cell lines. Cancer Lett 190: 165-169.

Ferreira-Machado SC, Rodrigues MP, Nunes APM, Dantas FJS, 
De Mattos JCP, Silva CR, Moura EG, Bezerra RJA, Caldeira-de-Araújo A 2004. Genotoxic potentiality of aqueous extract prepared from Chrysobalanus icaco L. leaves. Toxicol Lett 151: 481-487.

Guedes AP, Cardoso VN, De Mattos JC, Dantas FJ, Matos VC, Silva JC, Bezerra RJ, Caldeira-de-Araujo A 2006. Cytotoxic and genotoxic effects induced by stannous chloride associated to nuclear medicine kits. $\mathrm{Nucl}$ Med Biol 33: 915-921.

Gunstone FD, Subbarao R 1967. New tropical seed oils. Part I. conjugated trienoic and tetraenoic acids and their oxoderivatives in the seed oils of Chrysobalanus icaco and Parinarium laurinum. Chem Phys Lipids 1:349-359.

Gustafson KR, Munro MHG 1991. HIV inhibitory natural products: 3. Diterpenes from Homalanthus acuminatus and Chrysobalanus icaco. Tetrahedron 47: 4547-4554.

Javor T, Tarnok F, Past T, Nagy S 1986. Cytoprotective effect of free radical scavengers against mucosal damage produced by different antirheumatic drugs. Int $J$ Tissue React 8: 35-40.

Little EL-Jr, Woodbury RO, Wadswort FH 1974. Trees of Puerto Rico and the Virgin Islands, Agriculture Handbook 449, Vol.2. Washington, DC: U.S. Department of Agriculture.

Melo SF, Soares SF, Costa RF, Silva CR, Oliveira MBN, Bezerra RJ, Caldeira-de-Araújo A, Bernardo-Filho M 2001. Effect of the Cymbopogon citrans, Maytenus ilicifolia and Baccharis genistelloides extracts against the stannous chloride oxidative damage in Escherichia coli. Mutat Res 496: 33-38.

Mendez J, Bilia AR, Morelli I 1995. Phytochemical investigations of Licania genus. Flavonoids and triterpenoids from Licania pittieri. Pharma Acta Helv 70: 223-226.

Sambroock J, Fritsch EF, Maniatis T 1989. Extraction and purification of plasmid DNA. In: Molecular cloning. A laboratory manual. New York: Cold Spring Harbour Laboratory Press.

Simoes C, De Mattos JC, Sabino KC, Caldeira-de-Araujo A, Coelho MG, Albarello N, Figueiredo SF 2006. Medicinal potential from in vivo and acclimatized plants of Cleome rosea. Fitoterapia 77: 94-99.

Verma VS, Raychaudhuri SP 1972. Effect of catechol tannins isolated from a medicinal plant Chrysobalanus icaco on the infectivity of potato virus X. Zentralbl Bakteriol Parasitenkd Infektionskr Hyg 127: 178179. 